\title{
Trophic relationships and pelagic-benthic coupling during summer in the Barents Sea Marginal Ice Zone, revealed by stable carbon and nitrogen isotope measurements
}

\author{
Tobias Tamelander ${ }^{1,2,3, *}$, Paul E. Renaud ${ }^{4,2}$, Haakon Hop ${ }^{1}$, Michael L. Carroll ${ }^{2}$, \\ William G. Ambrose Jr. ${ }^{5,2}$, Keith A. Hobson ${ }^{6}$ \\ ${ }^{1}$ Norwegian Polar Institute, 9296 Tromsø, Norway \\ ${ }^{2}$ Akvaplan-niva, 9296 Tromsø, Norway \\ ${ }^{3}$ Norwegian College of Fishery Science, University of Tromsø, 9037 Tromsø, Norway \\ ${ }^{4}$ University of Connecticut, 1080 Shennecossett Road, Groton, Connecticut 06340, USA \\ ${ }^{5}$ Bates College, Lewiston, Maine 04240, USA \\ ${ }^{6}$ Canadian Wildlife Service, 115 Perimeter Road, Saskatoon, Saskatchewan S7N OX4, Canada
}

\begin{abstract}
Food web structure and pathways from primary production were studied in pelagic, sympagic (ice-associated) and benthic communities during summer in a seasonally ice covered region of the northern Barents Sea. Stable isotopes of carbon $\left(\delta^{13} C\right)$ and nitrogen $\left(\delta^{15} N\right)$ were used as tracers of organic material through marine food webs and trophic levels of organisms, respectively. Measurements of $\delta^{15} \mathrm{~N}$ show that sympagic amphipods occupy the lowest trophic levels (ca. 2), for primary consumers, followed by zooplankton (2.0 to 2.6), benthic suspension and deposit feeders (2.2 to 3.7 ), benthic carnivores (3.6 to 4.4 ) and fishes (3.3 to 4.4). The $\delta^{13} \mathrm{C}$ values indicate that zooplankton mainly graze on suspended particulate organic material (POM). Sympagic amphipods derive most of their energy from ice POM, but some species had $\delta^{13} \mathrm{C}$ values indicating that phytoplankton also contributes to their energy intake. $\delta^{13} \mathrm{C}$ values of some components of the benthic community suggest that POM settling out of the water column is efficiently exploited by the benthic fauna. Elevated $\delta^{13} \mathrm{C}$ values of the benthic fauna relative to zooplankton at some stations indicate that the degree of pelagic-benthic coupling at stations separated by only $90 \mathrm{~km}$ is determined by a combination of factors, including water-mass properties and the primary-production regime. These results may qualify findings of previous studies that have sampled from discrete locations or have pooled specimens collected from a broad area to make conclusions about food webs on a regional scale.
\end{abstract}

KEY WORDS: Stable isotopes $\cdot \delta^{13} \mathrm{C} \cdot \delta^{15} \mathrm{~N} \cdot$ Food web $\cdot$ Arctic $\cdot$ Barents Sea $\cdot$ Marginal Ice Zone Pelagic-benthic coupling

\section{INTRODUCTION}

Marginal Ice Zones (MIZs) are characterised by high annual primary production (Sakshaug \& Skjoldal 1989, Niebauer et al. 1990), with significant seasonal and inter-annual variability (Falk-Petersen et al. 2000b, Engelsen et al. 2002). The seasonal retreat of the seaice edge is often associated with a pronounced phytoplankton bloom, governed by entrainment of phytoplankton and nutrients in a shallow, mixed surface layer, formed due to ice melt (Niebauer et al. 1990, Strass \& Nöthig 1996, Engelsen et al. 2002). A latitudinal 'migration' of primary production, the so-called ice-edge effect, is a ubiquitous feature of seasonally ice-covered regions, and has a significant influence on food web structure and function in these regions (Sakshaug \& Skjoldal 1989, Hansen et al. 2003). Dynamic ice conditions, however, may result in an ill-defined ice edge, creating a mosaic of ice-covered and open-water areas, where spatial and temporal patterns in the tradi- 
tional MIZ bloom are decoupled (Falk-Petersen et al. 2000b, Engelsen et al. 2002).

There are 2 principal sources of primary production in the offshore Arctic MIZ; phytoplankton and ice algae (Sakshaug \& Skjoldal 1989). Phytoplankton is responsible for the bulk of the annual production, but is confined to open waters or leads in the ice, and phytoplankton blooms tend to occur later in the year than ice algal production. Ice algae are mostly represented by diatoms growing in dense layers within or attached to the underside of the ice from February until May or June, when melting starts (Syvertsen 1991). Legendre et al. (1992) estimated that ice algal production in the Arctic averages $10 \mathrm{~g} \mathrm{C} \mathrm{m}^{-2} \mathrm{yr}^{-1}$. In the Barents Sea MIZ, ice algae may contribute 16 to $22 \%$ to the annual primary production, depending on the extent of ice-free areas (Hegseth 1998). Thus, in years with extended ice cover, the ice algae may comprise an important fraction of the primary production and vertical particle export in seasonally ice-covered regions (Michel et al. 2002). Ice algal-based detritus is an important food source for the sympagic, i.e. iceassociated, fauna (Bradstreet \& Cross 1982, Poltermann 2001). The contribution of ice algae to the diet of other ecosystem components, i.e. zooplankton and benthos, however, remains to be quantified. Grazing by copepods on ice algae at the ice-water interface has been observed in the Canadian Arctic (Conover et al. 1986), which suggests that ice algae may be an important early season food source before phytoplankton become abundant.

The fate of primary production in Arctic shelf seas depends on the spatial and temporal variability in distribution and species composition of both the production regime and the pelagic grazers (Wassmann et al. 1996). From a food-web standpoint, phytoplankton- and ice algal-based organic material can either be retained in the upper water column or be exported to the benthos (e.g. Carroll \& Carroll 2003). Primary trophic pathways, therefore, are determined in large by the match or mismatch between pelagic herbivores and the peak of primary production (Eilertsen et al. 1989, Falk-Petersen et al. 1999). The degree of heterotrophy in the plankton community has considerable implications for the retention versus vertical export of surface primary production (Olli et al. 2002). The highest vertical carbon fluxes are typically recorded during spring (Andreassen \& Wassmann 1998), before the pelagic community has reached a state of development in which production and consumption are balanced (Olli et al. 2002, Verity et al. 2002, Sherr et al. 2003), resulting in a pulsed food supply to the benthos (Grebmeier et al. 1995, Wassmann et al. 1996). Benthic communities in Arctic shelf seas have been found to reflect the primary production regime of the overlying water column, in terms of bio- mass, abundance and production, which suggests a tight pelagic-benthic coupling in these regions (Grebmeier et al. 1988, Highsmith \& Coyle 1990, Ambrose \& Renaud 1995, Piepenburg et al. 1997).

Stable isotopes may permit the identification of energy sources assimilated by consumers, averaged over the turnover time for the species or tissue studied (Kling et al. 1992, Post 2002). In comparison, dietary analyses only provide a measure of recently ingested food, and are limited by the extent to which food items in stomachs can be identified. The stable isotope technique is particularly useful in food web studies in remote regions, such as the MIZ, where the possibility for long-term or high-frequency sampling is limited. When 2 isotopically distinct carbon sources are available to the food web, their relative importance can be estimated from the $\delta^{13} \mathrm{C}$ value of consumer tissue relative to those of endpoints, corresponding to each source (Fry \& Sherr 1984, Post 2002). Stable nitrogen isotopes (i.e. $\delta^{15} \mathrm{~N}$ values) can be used to estimate trophic levels of organisms in the community (Wada et al. 1987, Hobson \& Welch 1992). Previous isotope studies have shown that in some regions of the Arctic, benthic communities may receive a substantial amount of ungrazed POM from the overlying water column (Hobson \& Welch 1992, Hobson et al. 1995), whereas other regions are characterised by weaker pelagic-benthic coupling (McConnaughey \& McRoy 1979, Dunton et al. 1989, Hobson et al. 2002). Some recent studies also suggest that ice algae may comprise a significant proportion of the diets of some benthic organisms (Hobson et al. 2002, McMahon et al. 2006, this volume).

We used stable isotopes to study trophic relationships and the transfer of energy in pelagic, sympagic (ice-associated) and benthic communities, and in fish fauna in the north-western Barents Sea MIZ. The shallow, seasonally ice-covered Barents Sea borders the deep Arctic Ocean, which is ice-covered yearround. The hydrography of the Barents Sea is characterised by both Arctic and Atlantic water masses (Loeng 1991), resulting in a dynamic environmental setting and highly variable primary production regimes, which make this a complex region for the study of ecosystem structure and function (Falk-Petersen et al. 2000b, Engelsen et al. 2002). Consequently, we might expect trophic structures to vary spatially and temporally in response to ice cover, hydrographic parameters and production.

\section{MATERIALS AND METHODS}

Study area. The study area covers the north-western Barents Sea and the Arctic Ocean shelf-break region. Samples were collected from the RV 'Jan Mayen' 
(University of Tromsø) in July 2003 at stations located along a south-north transect between ca. 76 and $79^{\circ} \mathrm{N}$, approximately along the $30^{\circ} \mathrm{E}$ meridian east of Spitsbergen (Table 1, Fig. 1). During the time of sampling, all stations had a 40 to $70 \%$ ice cover, which consisted of 80 to $90 \%$ first-year ice (Table 1). The ice extended relatively far to the south, but was in a melting stage. CTD profiles showed that the water column at Stns I and IV was dominated by Atlantic water (AtW) overlain by colder water with Arctic characteristics (ArW). Stn II was located in a region separated from the Atlantic water influence by topographic control and dominated by ArW with lower salinity than at the stations further south. At Stn III, the water column was mostly composed of ArW, but the bottom layer (140 m to bottom) was dominated by AtW, likely a southward return-flow from the West Spitsbergen Current circulating around Spitsbergen to the north (A. Sundfjord, University of Bergen, pers. comm.).

Sampling and analyses. Particulate organic material (POM) from the ice and sympagic amphipods were sampled by SCUBA-diving below the ice. Ice POM and detritus were collected using $20 \mu \mathrm{m}$ mesh nets mounted in electrical suction pumps, whereas a $500 \mu \mathrm{m}$ mesh was used for animals. Depth-integrated water samples for suspended (water column) POM were collected with a Rosette sampler from 0, 5, 10 and $20 \mathrm{~m}$ depths. Samples of settling material were obtained from $24 \mathrm{~h}$ deployments of sediment traps, moored from the ice edge at 40,90 and $200 \mathrm{~m}$ depth. The traps (KC Denmark Research Equipment) had duplicate transparent cylinders, with an internal diameter of $7.2 \mathrm{~cm}$ and a $6: 1$ aspect ratio, mounted in a gimballed frame, equipped with a vane. Because some sediment trap samples were too small for stable isotope analyses, data from the same depths is not available from every station.

Sediment was sampled with a multicorer (Bowers \& Connely) containing 4 replicate tubes of $10 \mathrm{~cm}$ diameter. The sediment-surface nepheloid layer was sampled by siphoning the top millimetre of the sediment. Separate sediment samples were taken either from the multicorer or sub-sampled from box cores and sliced in $1 \mathrm{~cm}$ intervals to $5 \mathrm{~cm}$ depth. Samples of ice and suspended $\mathrm{POM}$, settling material, and the nepheloid layer were filtered on pre-combusted $\left(450^{\circ} \mathrm{C}, 4 \mathrm{~h}\right)$ Whatman $\mathrm{GF} / \mathrm{C}$ glass fibre filters and stored frozen at $-20^{\circ} \mathrm{C}$.

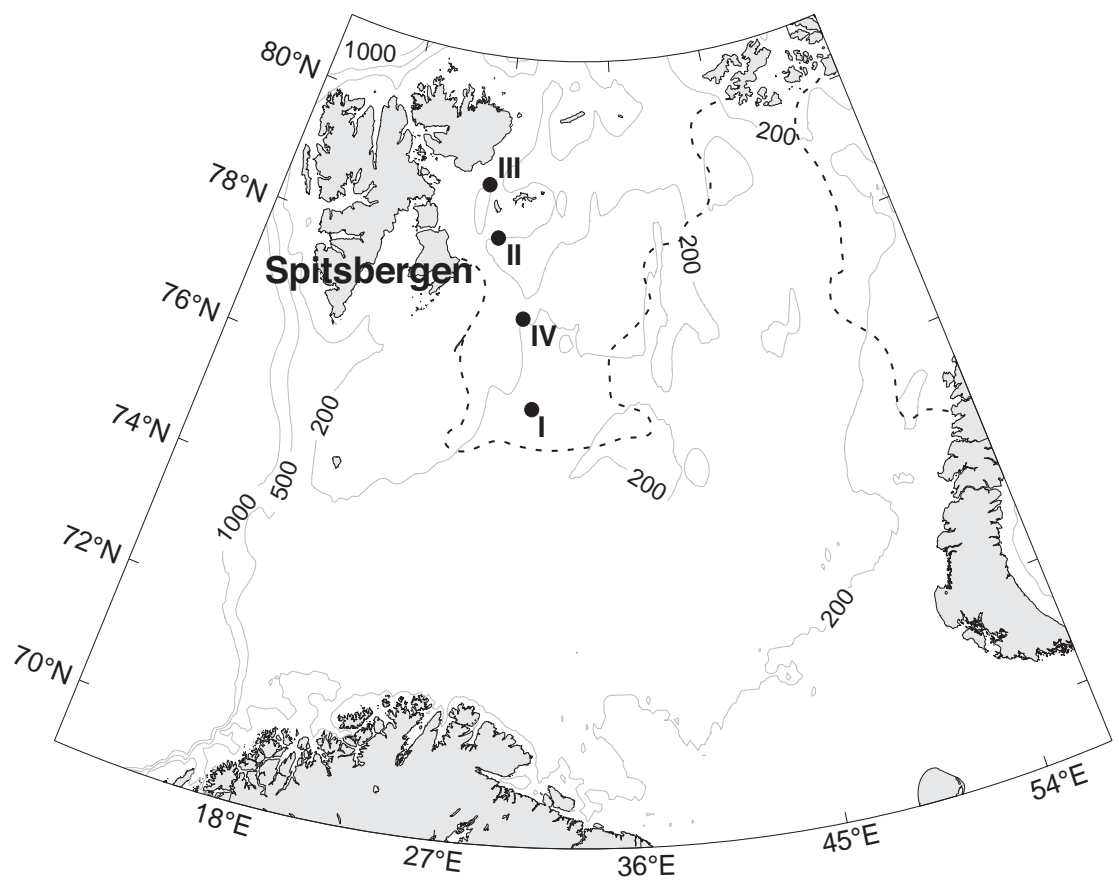

Fig. 1. Map of the studied region with bathymetry and main sampling locations indicated. Dashed line indicates approximate position of the ice edge (10 to $40 \%$ ice concentration) at the start of the cruise (10 July 2003)

Table 1. Stations visited, ice cover, proportions of first-year and multi-year and first-year ice (FYI/MYI), bottom depth, mixed layer depth (MLD), surface (mixed layer) and bottom (deepest $10 \mathrm{~m}$ ) temperature and salinity (mean \pm SD). Plankton, sympagic and benthic samples were collected at all main stations (I, II, III and IV). Stns IVa and IVb are bottom trawl (fish sampling) and horizontal MIK-trawl (zooplankton) stations, respectively

\begin{tabular}{|c|c|c|c|c|c|c|c|c|c|c|}
\hline \multirow[t]{2}{*}{ Stn } & \multirow{2}{*}{$\begin{array}{c}\text { Position } \\
\text { (latitude, longitude) }\end{array}$} & \multirow{2}{*}{$\begin{array}{c}\text { Date visited } \\
\qquad(2003)\end{array}$} & \multirow{2}{*}{$\begin{array}{c}\text { Ice coverage } \\
(\%)\end{array}$} & \multirow{2}{*}{$\begin{array}{c}\text { FYI/MYI } \\
(\%)\end{array}$} & \multirow{2}{*}{$\begin{array}{c}\text { Bottom } \\
\text { depth }(\mathrm{m})\end{array}$} & \multirow{2}{*}{$\begin{array}{l}\text { MLD } \\
(\mathrm{m})\end{array}$} & \multicolumn{2}{|c|}{ Temperature $\left({ }^{\circ} \mathrm{C}\right)$} & \multicolumn{2}{|c|}{ Salinity (psu) } \\
\hline & & & & & & & Surface & Bottom & Surface & Bottom \\
\hline I & $75^{\circ} 40.5^{\prime} \mathrm{N}, 30^{\circ} 15.4^{\prime} \mathrm{E}$ & $10 \mathrm{Jul}$ & $40-70$ & $90 / 10$ & 343 & 53 & $0.15 \pm 1.41$ & $0.06 \pm 0.03$ & $33.96 \pm 0.81$ & $34.92 \pm 0$ \\
\hline II & $78^{\circ} 14.8^{\prime} \mathrm{N}, 27^{\circ} 1.3^{\prime} \mathrm{E}$ & $14 \mathrm{Jul}$ & $40-70$ & $90 / 10$ & 319 & 35 & $-1.27 \pm 0.57$ & $0.26 \pm 0.02$ & $33.72 \pm 0.68$ & $34.85 \pm 0$ \\
\hline III & $79^{\circ} 2.1^{\prime} \mathrm{N}, 25^{\circ} 51.8^{\prime} \mathrm{E}$ & $16 \mathrm{Jul}$ & $50-70$ & $80 / 20$ & 213 & 43 & $-1.35 \pm 0.38$ & $1.87 \pm 0.12$ & $33.65 \pm 0.62$ & $34.74 \pm 0.03$ \\
\hline IV & $77^{\circ} 2.7^{\prime} \mathrm{N}, 29^{\circ} 18.9^{\prime} \mathrm{E}$ & $19 \mathrm{Jul}$ & $40-70$ & $90 / 10$ & 227 & 41 & $-1.52 \pm 0.19$ & $1.15 \pm 0.03$ & $33.91 \pm 0.58$ & $34.97 \pm 0$ \\
\hline IVa & $77^{\circ} 3.2^{\prime} \mathrm{N}, 28^{\circ} 19.1^{\prime} \mathrm{E}$ & $19 \mathrm{Jul}$ & 0 & - & $178-192$ & - & - & - & - & - \\
\hline $\mathrm{IVb}$ & $76^{\circ} 58.4^{\prime} \mathrm{N}, 29^{\circ} 1.7^{\prime} \mathrm{E}$ & $19 \mathrm{Jul}$ & 0 & - & 239 & - & - & - & - & - \\
\hline
\end{tabular}


Zooplankton was collected with vertical net tows from bottom to surface or bottom to $50 \mathrm{~m}$ with a WP2 net (mesh size $180 \mu \mathrm{m}$ ), and from bottom to surface with an MIK trawl ('Method Isaac Kidd'; mesh size $1000 \mu \mathrm{m}$, opening $3.14 \mathrm{~m}^{2}$ ). The MIK trawl was also used for horizontal tows in open waters close to the main stations (Table 1). Zooplankton and sympagic amphipods were sorted into species and size groups, and kept live in filtered seawater in screened, falsebottom chambers at ca. $0^{\circ} \mathrm{C}$ for 24 to $48 \mathrm{~h}$ until evacuation of gut contents. Several individuals of the same species and size (length or developmental stage) were combined in order to obtain sufficiently large samples.

Benthic invertebrates were collected from a triangular dredge (1 $\mathrm{m}$ per side) and from a Campelen 1800 bottom trawl (Table 1). Animals captured were sorted and kept in filtered seawater for evacuation of gut contents for 24 to $48 \mathrm{~h}$. Small animals, such as pycnogonids and polychaetes, were analysed whole. Bivalves and gastropods were analysed based on their soft parts or only muscle tissue (larger animals). Sea stars were dissected, and the part of the stomach protruding to the arms (i.e. the pyloric caecum) was removed. Analyses were generally performed on $1 \mathrm{arm}$ ind.$^{-1}$. Fish caught in the trawl were measured and dissected, and dorsal muscle samples were analysed for stable isotopes.

All samples were stored at $-20^{\circ} \mathrm{C}$ until analysis. Prior to analyses, all samples were rinsed in distilled water in order to remove salt. Lipids were removed from all samples in order to reduce the variability of $\delta^{13} \mathrm{C}$ values among species, seasons and developmental stages due to different body content of lipids, which are relatively depleted in ${ }^{13} \mathrm{C}$ (Attwood \& Peterson 1989, Hobson \& Welch 1992). Carbonates were removed as well (Hobson et al. 1995). Samples were dried at $60^{\circ} \mathrm{C}$, or freeze dried, and ground to a fine powder using mortar and pestle. Pre-treatment of the different types of samples differed slightly, as samples of the benthic fauna were analysed at the laboratory of K. Hobson (Saskatoon, Canada), whereas all other samples were analysed at the Institute for Energy Technology (Kjeller, Norway); these laboratories apply different methods for removal of carbonates and lipids.

Stable isotope ratios are expressed as a per mille (\%o) enrichment relative to international standards according to the relationship:

$$
\delta X=\left[\left(R_{\text {sample }} / R_{\text {standard }}\right)-1\right] \times 1000
$$

where $X$ is ${ }^{13} \mathrm{C}$ or ${ }^{15} \mathrm{~N}$ and $R$ is the corresponding ratio ${ }^{13} \mathrm{C} /{ }^{12} \mathrm{C}$ or ${ }^{15} \mathrm{~N} /{ }^{14} \mathrm{~N}$. Standards for $\delta^{13} \mathrm{C}$ and $\delta^{15} \mathrm{~N}$ are PeeDee Belemnite and atmospheric nitrogen $\mathrm{N}_{2}$ (air), respectively.

Parallel analyses of split samples revealed slight differences in the isotope enrichment values for some, although not all, species between the 2 laboratories (T. Tamelander unpubl. data). Even when statistically significant (maximum difference $1.1 \%$ for $\delta^{15} \mathrm{~N}$ and $1.4 \%$ or $\delta^{13} \mathrm{C}$ ), the differences were small and would only have minor relevance for the food web model as a whole. Assuming a $1.4 \%$ offset for all samples analysed at the Canadian laboratory, corresponding to the maximum difference between the 2 laboratories, and recounting the $\delta^{13} \mathrm{C}$ values accordingly would not affect our conclusions.

Trophic level values of consumer organisms were estimated assuming an average increase in $\delta^{15} \mathrm{~N}$ values of $3.4 \%$ between consecutive trophic levels ( $\mathrm{J}$. Søreide, Akvaplan-niva, Tromsø, pers. comm.). Previous food web studies have applied fractionation factors for $\delta^{15} \mathrm{~N}$ between 3 and $4 \%$ (Hobson et al. 1995, Post 2002, Bode et al. 2003, Iken et al. 2005). Trophic level values (TL) of consumer organisms were thus calculated according to the relationship:

$$
\mathrm{TL}=\left(\delta^{15} \mathrm{~N}_{\text {Consumer }}-\delta^{15} \mathrm{~N}_{\mathrm{PP}}\right) / 3.4+1
$$

where PP denotes primary producers (ice algae or phytoplankton, depending on the anticipated primary food source). The average $\delta^{15} \mathrm{~N}$ value of all samples of suspended POM $(4.7 \%$ ) , excluding 1 outlier, was used to calculate trophic levels of the pelagic, benthic and fish fauna, whereas the average ice algal $\delta^{15} \mathrm{~N}$ value $(4.8 \%$ ) was used for trophic levels of sympagic amphipods.

Statistical analyses. Statistical tests were performed using Statistica 7. The isotope data was not normally distributed (Shapiro-Wilk's test, $\mathrm{p}<0.05$ ), and nonparametric statistical tests were therefore applied. Mann-Whitney $U$-tests were used for testing differences between 2 independent samples. A KruskalWallis test, with a multiple comparisons post hoc test, was used for comparing several groups. For comparing the $\delta^{13} \mathrm{C}$ and $\delta^{15} \mathrm{~N}$ signatures between the different animal communities sampled (pelagic, sympagic, benthic and fishes), only data from Stn IV (Stns IV, IVa and IVb) where all groups were sampled, was included in the analysis.

\section{RESULTS}

\section{Stable isotope composition of particulate material and the biota}

The lowest $\delta^{13} \mathrm{C}$ values were found in suspended POM. Ice POM was significantly more enriched in ${ }^{13} \mathrm{C}$ than suspended POM (Mann-Whitney $U$-test, $\mathrm{p}=$ $0.004, \mathrm{n}=4$ and $\mathrm{n}=12$ for suspended and ice POM, respectively), but no difference was found for $\delta^{15} \mathrm{~N}$ (Mann-Whitney $U$-test, $\mathrm{p}=0.8, \mathrm{n}=4$ and $\mathrm{n}=9$ for 
suspended and ice POM, respectively). Material from the sediment traps had $\delta^{13} \mathrm{C}$ values that were 0.9 to $5.6 \%$ higher compared to the suspended POM (Fig. 2). Compared to settling POM, material from the sediment nepheloid layer was depleted in ${ }^{13} \mathrm{C}$ by 2.0 to $4.0 \%$ at Stns II, III and IV and enriched by $0.6 \%$ at Stn I. The sediment had consistently higher $\delta^{13} \mathrm{C}$ values than the nepheloid layer (Fig. 2).

Whereas ice fauna and zooplankton showed little variation in $\delta^{13} \mathrm{C}$ values among species, benthic invertebrates revealed a wide range in values (Table 2, Fig. 3). At Stn IV, where samples of all organism groups were collected, zooplankton and sympagic amphipods had significantly lower $\delta^{13} \mathrm{C}$ values than the benthos (KruskalWallis test, $\mathrm{p}<0.0001$, Table 3). Fishes were significantly more enriched in ${ }^{13} \mathrm{C}$ than zooplankton, but depleted by ca. $3 \%$ compared to benthos (KruskalWallis test, $\mathrm{p}<0.001$, Table 3). Zooplankton had the same $\delta^{15} \mathrm{~N}$ values as sympagic amphipods and benthos, whereas fishes had significantly higher values than all other groups (KruskalWallis test, $\mathrm{p}<0.001$, Table 3 ).

Zooplankton and ice fauna from all stations sampled were equally enriched in ${ }^{13} \mathrm{C}$ (Mann-Whitney $U$-test, $\mathrm{p}=0.5, \mathrm{n}$ $=55$ for ice fauna and $\mathrm{n}=51$ for zooplankton), with $\delta^{13} \mathrm{C}$ values around $-21 \%$. Zooplankton had significantly higher (ca. $3 \%$ ) $\delta^{15} \mathrm{~N}$ values than the ice fauna (Mann-Whitney U-test, p < 0.0001), however.

Within the group of sympagic amphipods, Apherusa glacialis and Onisimus glacialis had significantly higher $\delta^{13} \mathrm{C}$ and lower $\delta^{15} \mathrm{~N}$ values, respectively, than Gammarus wilkitzkii and Onisimus nanseni (Kruskal-Wallis tests, $\mathrm{p}<0.001$, Tables $2 \& 3$ ). Among the zooplankton species, the pelagic amphipod Themisto libellula had significantly lower $\delta^{13} \mathrm{C}$ values than Calanus hyperboreus and krill (Kruskal-Wallis test, $\mathrm{p}<0.001$, Table 3). Krill and T. libellula generally had higher $\delta^{15} \mathrm{~N}$ values than copepods (Table 2). A statistically significant difference was only found between Thysanoessa longicaudata and C. hyperboreus, however (KruskalWallis test, $\mathrm{p}<0.01$, Table 3 ).
Benthic amphipods had $\delta^{13} \mathrm{C}$ values around $-20 \%$, similar to pelagic and sympagic amphipods (Table 2). Low $\delta^{13} \mathrm{C}$ values were also observed in suspensionfeeding organisms, such as Bryozoa $(-22.7 \%$ ) and the

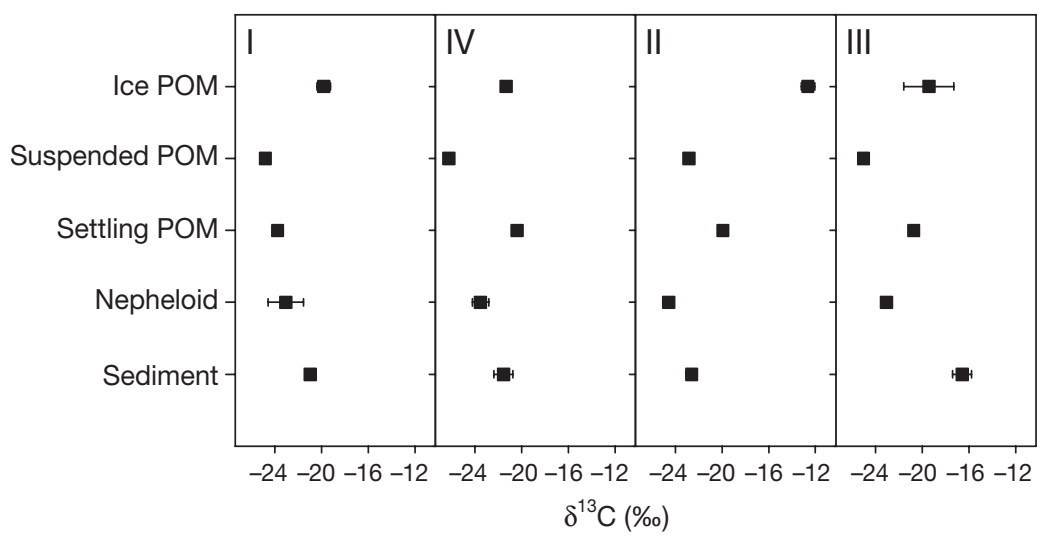

Fig. 2. $\delta^{13} \mathrm{C}$ values (\%) of ice POM (particulate organic matter), suspended and settling POM, the nepheloid layer and sediment. Bars show standard deviation for ice POM, nepheloid layer and sediment. Station numbers are indicated in upper left panel corners, and are presented from south to north. Sediment trap depths at Stn I: 200 m, Stn IV: 90 m, Stn II: 40 m and Stn III: 90 m

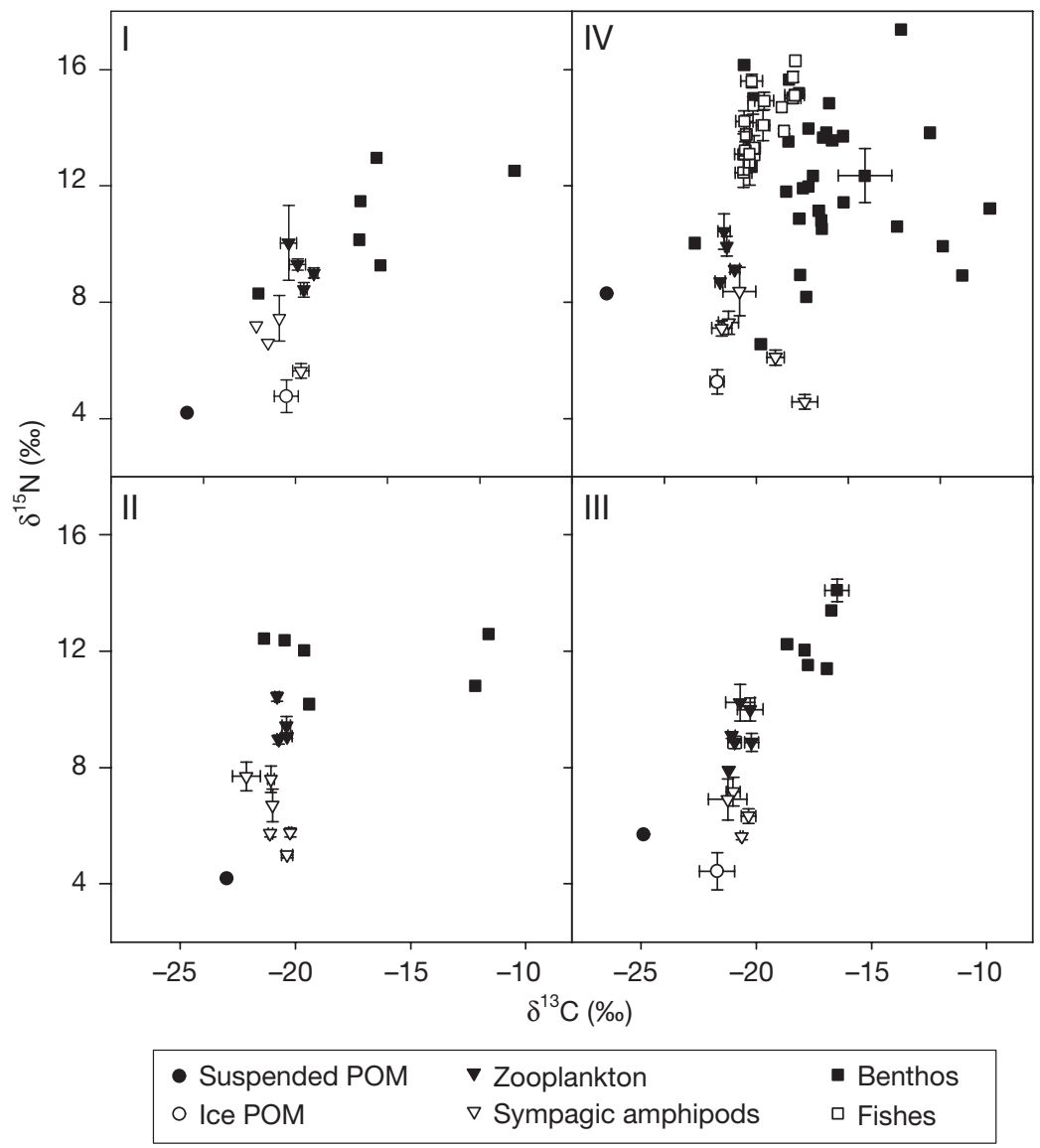

Fig. 3. Plots of $\delta^{13} \mathrm{C}$ and $\delta^{15} \mathrm{~N}(\%)$ values (means $\pm \mathrm{SD}$ ) for organisms in the Barents Sea food web. Station numbers are indicated in upper left panel corners 


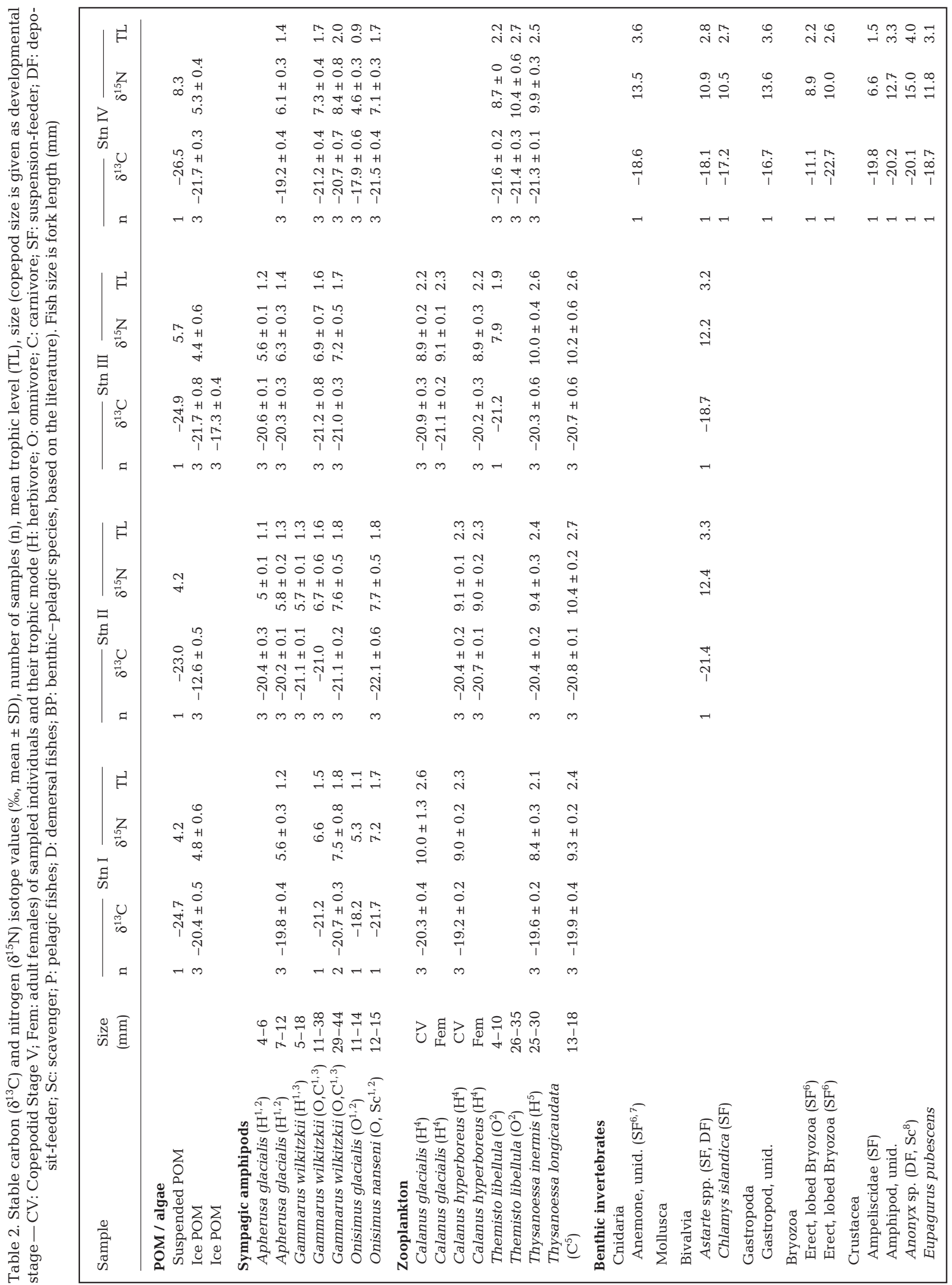




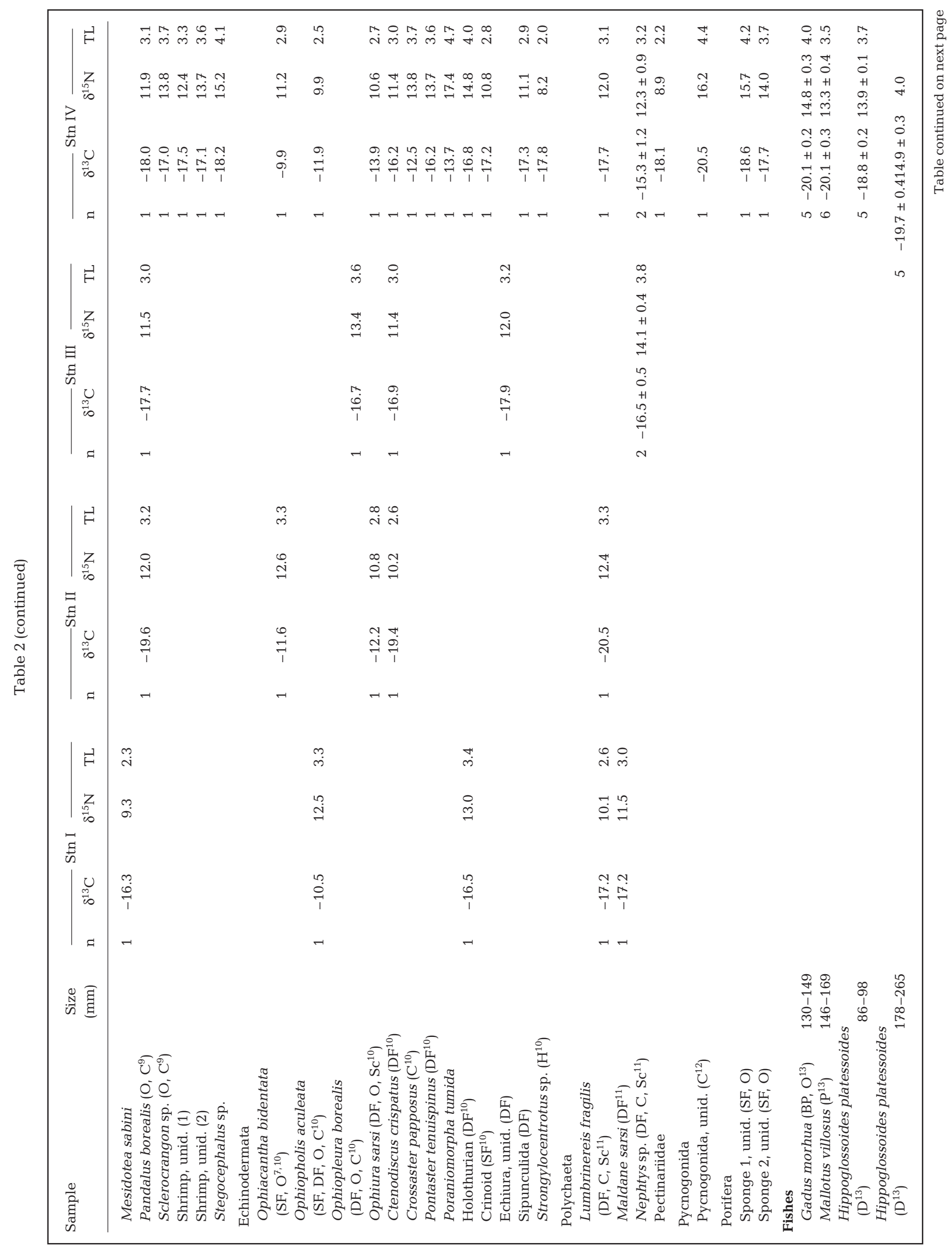




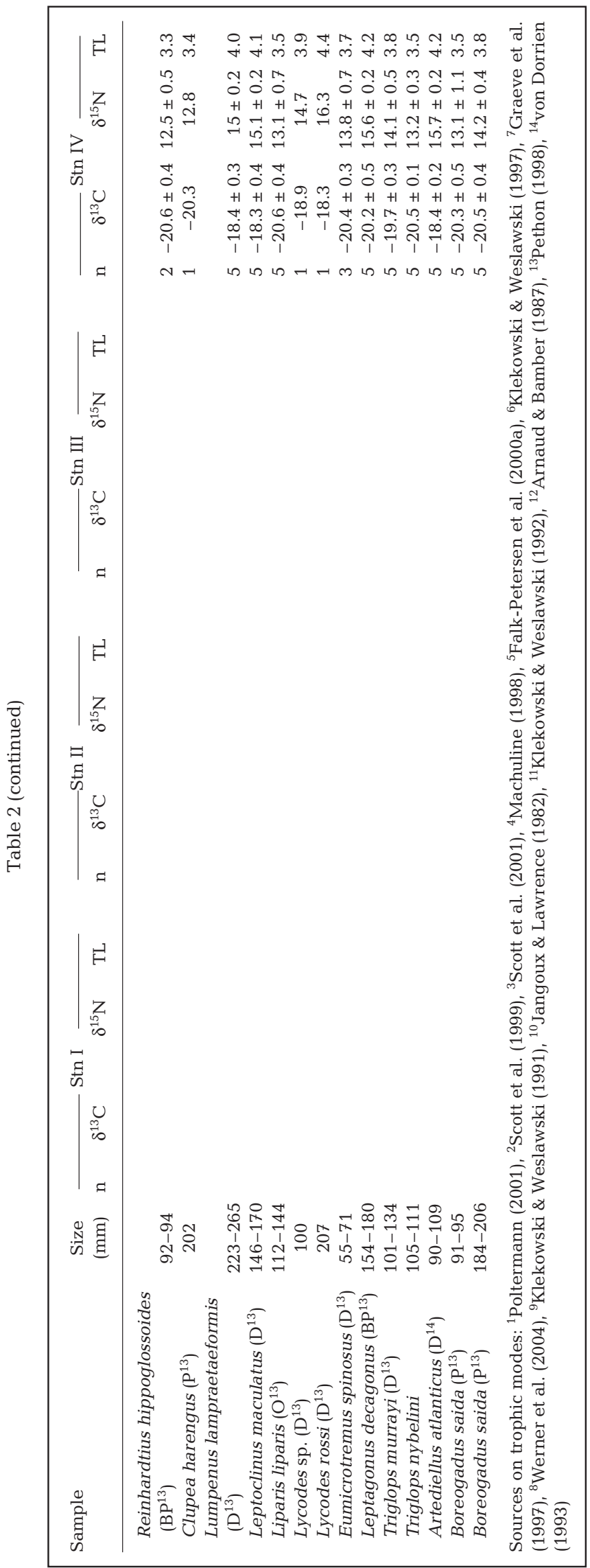

clam Astarte sp. (-21.4 to $-18.1 \%$ ). Deposit-feeding omnivorous decapods and polychaetes generally had higher $\delta^{13} \mathrm{C}$ values ( -20.5 to $-15.3 \%$ ). The highest $\delta^{13} \mathrm{C}$ values were observed in the brittle stars Ophiura sarsi and Ophiacantha bidentata (-12.2 and $-9.9 \%$, respectively, Table 2).

Of the fishes sampled at IVa, 2 groups with different $\delta^{13} \mathrm{C}$ values could be identified (Table 2). Demersal fishes were significantly more enriched than pelagic species (Mann-Whitney $U$-test, $\mathrm{p}<0.0001, \mathrm{n}=37$ for pelagic and $n=33$ for demersal fishes).

\section{Spatial variations in $\delta^{13} \mathrm{C}$}

The $\delta^{13} \mathrm{C}$ values of suspended POM were elevated at Stn II $(-23.0 \%)$ compared to Stns I, III and IV (-26.5 to $-24.7 \%$, Table 2$)$. The $\delta^{13} \mathrm{C}$ values of the settling material generally followed those of the suspended POM (Fig. 2). Zooplankton generally had $\delta^{13} \mathrm{C}$ values reflecting those of the suspended POM, although with a narrower range (-21.6 to $-19.2 \%$ ) (Fig. 3). The $\delta^{13} \mathrm{C}$ values of the benthic fauna, however, showed an opposite trend compared to the suspended POM and the zooplankton. Several species (Astarte sp., Pandalus borealis, Lumbrinereis fragilis, Ctenodiscus crispatus) had lower $\delta^{13} \mathrm{C}$ values at Stn II than at the other stations. At Stn II, the $\delta^{13} \mathrm{C}$ values of these species ranged from -21.4 to $-19.4 \%$, which is approximately the same as for pelagic grazers (Fig. 3). At Stns I, III and IV, the same species had $\delta^{13} \mathrm{C}$ values between -18.7 and $-16.2 \%$, more than $3 \%$ higher than for pelagic grazers (Table 2).

\section{DISCUSSION}

Our results demonstrate a variable degree of pelagic-benthic coupling over a relatively small spatial scale. At 1 location, fresh phytodetritus reached the seabed and was efficiently exploited by the benthos, as indicated by the similarity in $\delta^{13} \mathrm{C}$ values for the suspension- and surface-depositfeeding benthos and pelagic grazers. At other locations, higher enrichment of ${ }^{13} \mathrm{C}$ in the benthos relative to the zooplankton and sympagic fauna suggests weaker pelagic-benthic coupling. Distribution of water masses and the associated primary production regime seem to be important factors governing pelagic-benthic coupling in the northern Barents Sea. The spatial heterogeneity of the system is a feature that needs to be considered in food web studies in environments characterised by complex and dynamic environmental settings, such as marginal ice zones. 
Table 3. Summary of results from Kruskal-Wallis multiple comparisons tests. Animal groups or species are arranged from left to right in order of increasing $\delta^{13} \mathrm{C}$ (less negative) or $\delta^{15} \mathrm{~N}$ values. Statistically homogeneous groups ( $\left.\mathrm{p}>0.05\right)$ are marked with lines (Zp: zooplankton; Sa: sympagic amphipods; F: fishes; B: benthos; On: Onisimus nanseni; Gw: Gammarus wilkitzkii; Ag: Apherusa glacialis; Og: Onisimus glacialis; Tl: Themisto libellula; Cg: Calanus glacialis; T lo: Thysanoessa longicaudata; Ch: Calanus hyperboreus; Ti: Thysanoessa inermis)

\begin{tabular}{|c|c|c|c|c|c|c|c|c|c|}
\hline Comparison & Isotope & Stations included & $\mathrm{N}$ & p-value & 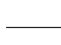 & - & compa & 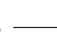 & 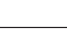 \\
\hline \multirow[t]{2}{*}{ Animal groups } & $\delta^{13} \mathrm{C}$ & IV & 134 & $<0.0001$ & $\mathrm{Zp}$ & $\mathrm{Sa}$ & $\mathrm{F}$ & B & \\
\hline & $\delta^{15} \mathrm{~N}$ & IV & 134 & $<0.0001$ & $\mathrm{Sa}$ & $\mathrm{Zp}$ & B & $\bar{F}$ & \\
\hline \multirow[t]{2}{*}{ Sympagic fauna } & $\delta^{13} \mathrm{C}$ & I, II, III, IV & 54 & $<0.0001$ & On & Gw & $\mathrm{Ag}$ & $\mathrm{Og}$ & \\
\hline & $\delta^{15} \mathrm{~N}$ & I, II, III, IV & 53 & $<0.0001$ & $\mathrm{Og}$ & $\mathrm{Ag}$ & $\mathrm{Gw}$ & On & \\
\hline \multirow[t]{2}{*}{ Zooplankton } & $\delta^{13} \mathrm{C}$ & I, II, III, IV & 51 & 0.0003 & $\mathrm{Tl}$ & $\mathrm{Cg}$ & T lo & $\mathrm{Ch}$ & $\mathrm{Ti}$ \\
\hline & $\delta^{15} \mathrm{~N}$ & I, II, III, IV & 51 & 0.005 & $\mathrm{Ch}$ & $\mathrm{Tl}$ & $\mathrm{Cg}$ & $\mathrm{Ti}$ & T lo \\
\hline
\end{tabular}

\section{Sources of organic $\mathrm{C}$ to the food web}

Suspended POM, derived mainly from phytoplankton, was found to have significantly lower $\delta^{13} \mathrm{C}$ values than ice POM ( -24.8 versus $-20.3 \%$, on average), although there was considerable variability in values for both groups. Samples collected in the following summer (2004) at stations further north at the shelf break and in the Arctic Ocean revealed the same pattern, although the $\delta^{13} \mathrm{C}$ values of both suspended POM and ice POM were depleted by ca. $2 \%$ compared to the 2003 data (T. Tamelander unpubl. data). Similar enrichment patterns have been observed in other regions of the Arctic (Hobson et al. 1995, Cooper et al. 2002) as well as the Antarctic (Gibson et al. 1999). The wide range in $\delta^{13} \mathrm{C}$ values in both groups probably reflects short-term variations in growth conditions, $\mathrm{CO}_{2}$ limitation and species-specific differences in isotope fractionation (Rau et al. 1992, Kopczynska et al. 1995, Fry 1996, Ostrom et al. 1997). Samples of ice POM and suspended POM were most likely dominated by autotrophic algal cells, but may have included a variable fraction of heterotrophic microorganisms and detritus, which could have increased the stable isotope values of these samples (Kopczynska et al. 1995).

Material collected in the sediment traps between 40 and $200 \mathrm{~m}$ depth was derived mainly from the suspended POM. The $\delta^{13} \mathrm{C}$ values of the sediment were mostly within the range of $\delta^{13} \mathrm{C}$ values of ice POM and suspended POM, which shows that autochthonous phytoplankton and ice algae both contribute to the organic material buried in the sediment of the Barents Sea MIZ (Fig. 2). The relative proportion of ice algae to the vertical particle flux may, however, be higher earlier in the season. A significant input of either macroalgal detritus or terrestrial plant material would likely have affected the $\delta^{13} \mathrm{C}$ values of the sediment, as these were respectively enriched and depleted in ${ }^{13} \mathrm{C}$ relative to phytoplankton (Fry \& Sherr 1984, Fredriksen 2003). Allochthonous sources of organic material therefore seem to be of minor importance in this region. The sediment nepheloid layer was generally depleted in ${ }^{13} \mathrm{C}$ compared to the settling material. One possible mechanism for this would be bacterial degradation of material reaching the seabed. Bacteria are generally enriched in ${ }^{13} \mathrm{C}$ compared to their substrate (Macko \& Estep 1984, Coffin et al. 1989), resulting in a depletion of ${ }^{13} \mathrm{C}$ in the remnant material (Lehmann et al. 2002). In the Northeast Water Polynya, Ritzrau \& Thomsen (1997) found that bacterial activity was significantly higher in the benthic boundary layer than in the water column, and that bacteria in the benthic boundary layer responded rapidly to the input of fresh phytodetritus. Organic material may therefore be modified in the nepheloid layer before it is incorporated in the sediment (Ritzrau \& Thomsen 1997, Lovvorn et al. 2005). In the Barents Sea, Thomsen \& Graf (1994) estimated that bacteria may comprise $15 \%$ of the POC in the benthic boundary layer.

\section{Trophic relationships in the northern Barents Sea}

Pelagic grazers receive most of their energy from suspended POM. Trophic level values of the copepods Calanus glacialis and C. hyperboreus between 2.2 and 2.6, however, suggest that their diet includes a fraction of the suspended POM with elevated $\delta^{15} \mathrm{~N}$ values. The $\delta^{15} \mathrm{~N}$ value of phytoplankton and suspended POM is influenced by a variety of factors, including nitrogen limitation (Pennock et al. 1996), inter-specific differences in isotope fractionation (Needoba et al. 2003), 
form of nitrogen assimilated (i.e. nitrate vs. ammonium, e.g. Ostrom et al. 1997) and grazing by protists (Hoch et al. 1996). Verity et al. (2002) estimated that microzooplankton was capable of grazing 64 to $97 \%$ of the daily chlorophyll production in the surface layer in the Barents Sea during summer. It is possible that microzooplankton, at least during a part of the productive season, provides an important link between primary producers and mesozooplankton in the Arctic pelagic marine ecosystem (Sato et al. 2002). A contribution of heterotrophic cells to the diet of zooplankton could also account for the 2.3 to $5.2 \%$ steps in $\delta^{13} \mathrm{C}$ values between suspended POM and pelagic grazers (Table 2, Kopczynska et al. 1995).

Based on their respective stable isotopic compositions, the sympagic amphipods Onisimus glacialis and Apherusa glacialis are primarily herbivorous, deriving a proportionately larger fraction of their energy directly from ice POM. In contrast, Gammarus wilkitzkii and Onisimus nanseni forage on pelagic prey in addition to grazing on POM. This interpretation agrees with dietary and lipid-biomarker studies (Scott et al. 1999, Poltermann 2001, T. Tamelander unpubl. data). Krill and pelagic amphipods had slightly higher trophic level values than the copepods. Consistently low $\delta^{13} \mathrm{C}$ values in the zooplankton, however, suggest that all species to some degree feed directly on suspended POM.

Suspension-feeding bivalves and bryozoans at 1 station (Stn II) had $\delta^{13} \mathrm{C}$ values comparable to pelagic copepods, indicating that fresh phytodetritus reaching the seabed was immediately exploited by the benthic community at this location (Fig. 3). Previous isotope studies in the Arctic have shown this to be the case at least in the Chukchi Sea (Dunton et al. 1989) and in the Northeast Water Polynya (Hobson et al. 1995). Suspension feeders had $\delta^{15} \mathrm{~N}$ values corresponding to TL 2.2 to 3.3. Deposit-feeding isopods, decapods, polychaetes and echinoderms occupied TL 2.3 to 3.6. Scavengers (the polychaete Nephtys sp., brittle stars Ophiura spp., the amphipod Anonyx sp.) were at TL 2.7 to 4.0 , whereas predators such as sea spiders (Pycnogonida) and the sea star Crossaster papposus occupied TL 3.7 to 4.4 (Table 2). No information was found on the feeding behaviour of the sea star Poraniomorpha tumida, but the high $\delta^{15} \mathrm{~N}$ value, corresponding to TL 4.7, suggests that it is mainly a carnivore or scavenger.

The highest $\delta^{13} \mathrm{C}$ values were observed in brittle stars. A wide range of $\delta^{13} \mathrm{C}$ values have been reported in this group elsewhere in the Arctic. Ophiura sarsi and Ophiacantha bidentata collected in the Northeast Water Polynya had $\delta^{13} \mathrm{C}$ values of -18.0 and $-22.0 \%$, respectively (Hobson et al. 1995). The $\delta^{13} \mathrm{C}$ value of $O$. sarsi collected in the north-central Bering Sea $(-19.0 \%$; Lovvorn et al. 2005) was in the same range, whereas values from the North Water Polynya and Chukchi Sea, $-11.3 \%$ (Hobson et al. 2002) and -11.1\%o (W. G. Ambrose unpubl. data), respectively, were similar to the level in the northern Barents Sea. Unidentified deep-sea ophiuroids in the Canada Basin (NW Canada) had $\delta^{13} \mathrm{C}$ values between -23.5 and $-20.8 \%$ (Iken et al. 2005). These regional variations may reflect a highly flexible omnivorous feeding strategy, and an ability to switch feeding strategy depending on available resources (Jangoux \& Lawrence 1982, Graeve et al. 1997). Brittle stars occupied trophic levels 2.6 to 3.6, the same as polychaetes, crustaceans and bivalves, but their higher $\delta^{13} \mathrm{C}$ values suggest that brittle stars may utilise a proportionally different array of food sources. Feeding on isotopically heavy ice POM reaching the seabed early in the season could increase their $\delta^{13} \mathrm{C}$ values. However, when accounting for a trophic enrichment of ca. $1 \%$ between diet and consumer (Michener \& Schell 1994), -14 to $-10 \%$ still seem high, since ice POM generally had $\delta^{13} \mathrm{C}$ values between -17 and $-21 \%$. Input of allochthonous material with higher $\delta^{13} \mathrm{C}$ values, such as kelp (Fredriksen 2003), was not likely an important food source, as the $\delta^{13} \mathrm{C}$ values of the nepheloid layer indicate that phytoplankton and ice algae were the most important sources of organic material reaching the seabed. Different biochemical fractionation pathways in different organism groups, or a faster turnover of body carbon than nitrogen when shifting from an herbivorous to a carnivorous diet, could perhaps contribute to the observed pattern of comparably low $\delta^{15} \mathrm{~N}$ and high $\delta^{13} \mathrm{C}$ values in this group.

The wider range in $\delta^{13} \mathrm{C}$ and $\delta^{15} \mathrm{~N}$ values of benthic organisms compared to zooplankton and ice fauna is consistent with the higher number of species, feeding strategies and habitat types that are represented in the benthic samples (Fig. 3). The variation in $\delta^{13} \mathrm{C}$ values of the benthos among stations probably reflects more persistent differences in energy input and utilisation in the benthic community rather than seasonal variations in $\delta^{13} \mathrm{C}$ values of the POM reaching the seabed.

Demersal fishes such as Atlantic hookear sculpin Artediellus atlanticus, eelpouts Lycodes spp. and long rough dab Hippoglossoides platessoides generally had higher $\delta^{13} \mathrm{C}$ values than herring Clupea harengus and capelin Mallotus villosus, which primarily feed on zooplankton, or Atlantic cod Gadus morhua and polar cod Boreogadus saida, which may both forage on zooplankton and selectively on benthic invertebrates ( $G$. morhua) or ice fauna (B. saida). Demersal fishes also tended to occupy slightly higher trophic levels than pelagic species, although the $\delta^{15} \mathrm{~N}$ values did not differ significantly between these groups. Fishes in the respective groups were of similar size, and the stable isotope composition therefore presumably reflects 
feeding habits rather than size effects. Fishes in our study had trophic levels in the upper range of values reported from the same or other regions of the Arctic. We calculated mean TLs of 4.0 and 3.8 for juvenile $G$. morhua and adult B. saida, respectively. For individuals of the same size range as in our study, Hop et al. (2002) estimated a TL of 3.2 for G. morhua in the Barents Sea near Bear Island. In other Arctic studies, $B$. saida's TL has ranged from around 3.2 to 3.7 (Hobson \& Welch 1992, Hobson et al. 1995, 2002). The demersal fishes Triglops nybelini and Lycodes rossi were 0.2 and 0.7 TL higher, respectively, than in the Northeast Water Polynya food web (Hobson et al. 1995). Since most values stem from the summer months (Hobson \& Welch 1992, Hobson et al. 1995, Hop et al. 2002), these variations are probably diet related, reflecting slightly different trophic positions of fishes across the Arctic. The use of a smaller fractionation factor for the Barents Sea food chain in this study $(3.4 \%$ ) compared to the others $(3.8 \%)$ would also slightly inflate TL values.

\section{Spatial variability of the pelagic-benthic coupling}

The higher $\delta^{13} \mathrm{C}$ values of the suspended POM and settling material at Stn II compared to the other stations likely reflected different successional stages of the phytoplankton bloom (Kopczynska et al. 1995, Ostrom et al. 1997). Stn II was characterised by nutrient depletion in the upper $10 \mathrm{~m}$ and a high chlorophyll biomass below $20 \mathrm{~m}$, dominated by diatoms, indicating bloom conditions. Stn III exhibited a similar pattern, but low primary production rates suggested that the bloom was declining. At Stn I, the bloom was likely in a late stage, indicated by nutrient depletion in the surface layer and a deep chlorophyll maximum, with a lower abundance of diatoms, whereas at Stn IV, the bloom was in an earlier stage, since nutrients still remained in the surface layer (H. Hodal, S. Kristiansen, M. Reigstad, Norwegian College of Fishery Science, University of Tromsø, and T. Ratkova, Shirshov Institute of Oceanology, Moscow, pers. comms.). The $\delta^{13} \mathrm{C}$ value of phytoplankton has been shown to increase progressively with decreasing concentrations of $\mathrm{CO}_{2}$ during a bloom (Rau et al. 1992, Ostrom et al. 1997). In the Southern Ocean, Kopczynska et al. (1995) found that pennate diatoms and heterotrophic dinoflagellates were associated with increased $\delta^{13} \mathrm{C}$ values of the suspended POM, whereas centric diatoms and flagellates, such as Phaeocystis sp., and autotrophic dinoflagellates caused depleted $\delta^{13} \mathrm{C}$ values. The elevated $\delta^{13} \mathrm{C}$ value of suspended POM at Stn II (-23.0\%) compared with the other stations ( -24.7 to $-26.5 \%$ ) was, therefore, likely caused by the dense diatom bloom at this station.
The similarity in $\delta^{13} \mathrm{C}$ values for the suspension-feeding benthos and zooplankton at Stn II suggests that these groups derive their energy from a common food source (Fig. 3), and, hence, there is strong pelagic-benthic coupling in this region (Hobson et al. 1995). The bloom conditions observed in the surface layer at Stn II and the $\delta^{13} \mathrm{C}$ values of the benthic community (Table 2 ) suggest diatom-based primary production to be the most likely source. At other stations the differences in $\delta^{13} \mathrm{C}$ values between the pelagic and benthic food webs were more pronounced, perhaps indicating a weaker coupling between surface primary production and benthic animal communities. It is uncertain if these among-station differences represent a persistent spatial heterogeneity of pelagic-benthic coupling in this region, or if they reflect the stage of the phytoplankton bloom and timing of sedimentation at the individual stations.

The elevated $\delta^{13} \mathrm{C}$ values of the benthic fauna at Stns I, III and IV are not easily explained (Fig. 3). Trophic fractionation of stable carbon isotopes increases the $\delta^{13} \mathrm{C}$ of a consumer by 0.5 to $1 \%$ relative to the diet (Michener \& Schell 1994), but the benthic organisms were enriched by $>7 \%$ relative to suspended POM. The following factors could potentially have contributed to the elevated $\delta^{13} \mathrm{C}$ values in benthic organisms compared to the zooplankton in the AtW region.

The benthic communities in regions dominated by AtW may receive a larger proportion of their energy from degraded material than communities in the ArW region (McConnaughey \& McRoy 1979, Hobson et al. 1995). Reworking of organic material by the benthic community and feeding on detritus with associated microfauna could increase the overall $\delta^{13} \mathrm{C}$ value of the benthic food web (Macko \& Estep 1984, Coffin et al. 1989, Lovvorn et al. 2005).

It is possible that ambient temperature may affect stable isotope fractionations between diet and consumer tissues. Power et al. (2003) showed that freshwater zooplankton raised at $26.5^{\circ} \mathrm{C}$ were enriched in $\delta^{13} \mathrm{C}$ by $3.1 \%$ relative to their diet, whereas animals raised at $12.5^{\circ} \mathrm{C}$ were enriched by only $1.7 \%$. The effect on $\delta^{15} \mathrm{~N}$ values was opposite. Applying these results to our data should be performed with caution, however, as they stem from experiments with different organisms and environments and were performed at higher temperatures than in our study. Bottom water temperatures only ranged from 0.06 to 1.9 among stations and it is unlikely that this would have caused a higher $\delta^{13} \mathrm{C}$ fractionation at the warmer stations.

The higher $\delta^{13} \mathrm{C}$ values of the suspension- and surface-deposit-feeding benthos compared to zooplankton indicate that isotopically light POM exported from the surface during non-diatom bloom conditions does not contribute much to the benthic energy intake. The benthic fauna therefore seems to be dependent on the 
episodic primary production events giving rise to pulses of vertical export of ungrazed material, conditions that are commonly associated with diatom blooms (Wassmann et al. 1996, Tamelander \& Heiskanen 2004). Early season sedimentation of ice algae, mostly represented by diatoms, could provide an additional input of energy to the benthic community.

Our results show that tight linkages between surface primary production and benthic animal communities in the northern Barents Sea are mainly governed by diatom blooms during which rapid sedimentation of ungrazed POM occurs. The distribution of different water masses and dynamic bloom conditions seems to give rise to spatial heterogeneities in the pelagicbenthic coupling in this region, as revealed by the different $\delta^{13} \mathrm{C}$ values of benthic organisms relative to zooplankton at stations dominated by AtW and ArW, respectively. Previous isotope studies in the Arctic have assessed the average food web structure of special types of environments such as polynyas (Hobson et al. 1995, 2002) or examined geographical trends in isotope signatures over wide geographical areas (Dunton et al. 1989, Saupe et al. 1989, France et al. 1998). Our findings show that 'average' food web models based on isotope signatures gathered from a large geographical area may easily oversee important aspects of the structure and function of the food web. In a complex environment such as the MIZ, spatial variability may likewise induce errors in extrapolations from singlesite observations to a regional scale.

Acknowledgements. This study was supported by the Norwegian Research Council, NORDKLIMA programme (CABANERA Project 155936/700), the National Science Foundation, Arctic Natural Sciences Program (OPP-0326371 to P.E.R. and OPP-0514115 to W.G.A.) and by an operating grant to K.A.H. from Environment Canada. We greatly acknowledge the assistance of the crew of RV 'Jan Mayen' and SCUBA diver T. Johansen during the field work. B. X. Alvarez assisted with isotopic measurements, which were conducted by M. Stocki at the Department of Soil Science, University of Saskatchewan. The map was drawn in Matlab using R. Pawlowicz's m_map. Three anonymous referees are acknowledged for excellent reviews of the manuscript. A. Sundfjord (Univ. of Bergen) is thanked for discussions on the Barents Sea physical oceanography and for comments on the manuscript.

\section{LITERATURE CITED}

Ambrose WG, Renaud PE (1995) Benthic response to water column productivity patterns: evidence for benthicpelagic coupling in the Northeast Water Polynya. J Geophys Res 100:4411-4421

Andreassen I, Wassmann P (1998) Vertical flux of phytoplankton and particulate biogenic matter in the marginal ice zone of the Barents Sea in May 1993. Mar Ecol Prog Ser 170:1-14

Arnaud F, Bamber RN (1987) The biology of Pycnogonida. Adv Mar Biol 24:1-96
Attwood CG, Peterson WT (1989) Reduction in fecundity and lipids of the copepod Calanus australis (Brodskii) by strongly pulsed upwelling. J Exp Mar Biol Ecol 129:121-131

Bode A, Carrera P, Lens S (2003) The pelagic foodweb in the upwelling ecosystem of Galicia (NW Spain) during spring: natural abundance of stable carbon and nitrogen isotopes. ICES J Mar Res 60:11-22

Bradstreet MSW, Cross WE (1982) Trophic relationships at high Arctic ice edges. Arctic 35:1-12

Carroll ML, Carroll J (2003) The Arctic Seas. In: Black K, Shimmield G (eds) Biogeochemistry of marine systems. Blackwell Publishing, Oxford, p 127-156

Coffin RB, Fry B, Wright RT (1989) Carbon isotopic compositions of estuarine bacteria. Limnol Oceanogr 34:1305-1310

Conover RJ, Herman AW, Prinsenberg SJ, Harris LR (1986) Distribution of and feeding by the copepod Pseudocalanus under fast sea ice during the Arctic spring. Science 232:1245-1247

Cooper LW, Grebmeier JM, Larsen IN, Egorov VG, Theodorakis C, Kelly HP, Lovvorn JR (2002) Seasonal variation in sedimentation of organic materials in the St. Lawrence Island polynya region, Bering Sea. Mar Ecol Prog Ser 226:13-26

Dunton KH, Saupe SM, Golikov AN, Schell DM, Schonberg SV (1989) Trophic relationships and isotopic gradients among arctic and subarctic marine fauna. Mar Ecol Prog Ser 56:89-97

Eilertsen HC, Tande KS, Hegseth EN (1989) Potential of herbivorous copepods for regulating the spring phytoplankton bloom in the Barents Sea. Rapp P-V Reun Cons Int Explor Mer 188:154-163

Engelsen O, Hegseth EN, Hop H, Hansen E, Falk-Petersen S (2002) Spatial variability of chlorophyll-a in the Marginal Ice Zone of the Barents Sea, with relations to sea ice and oceanographic conditions. J Mar Syst 35:79-97

Falk-Petersen S, Pedersen G, Hop H, Hegseth EN, Kwasniewski S (1999) Spatial distribution and life-cycle timing of zooplankton in the Marginal Ice Zone of the Barents Sea during summer melt season in 1995. J Plankton Res 20:1249-1264

Falk-Petersen S, Hagen W, Kattner G, Clarke A, Sargent JR (2000a) Lipids, trophic relationships and biodiversity in Arctic and Antarctic krill. Can J Fish Aquat Sci 57:178-191

Falk-Petersen S, Hop H, Budgell WP, Hegseth EN and 5 others (2000b) Physical and ecological processes in the marginal ice zone of the northern Barents Sea during the summer melt period. J Mar Syst 27:131-159

France R, Loret J, Mathews R, Springer J (1998) Longitudinal variation in zooplankton $\delta^{13} \mathrm{C}$ through the Northwest Passage: inference for incorporation of sea-ice POM into pelagic foodwebs. Polar Biol 20:335-341

Fredriksen S (2003) Food web studies in a Norwegian kelp forest based on stable isotope $\left(\delta^{13} \mathrm{C}\right.$ and $\left.\delta^{15} \mathrm{~N}\right)$ analysis. Mar Ecol Prog Ser 260:71-81

Fry B $(1996){ }^{13} \mathrm{C} /{ }^{12} \mathrm{C}$ fractionation by marine diatoms. Mar Ecol Prog Ser 134:283-294

Fry B, Sherr EB (1984) $\delta^{13} \mathrm{C}$ measurements as indicators of carbon flow in marine and freshwater ecosystems. Contrib Mar Sci 27:13-47

Gibson JAE, Trull T, Nichols PD, Summons RE, McMinn A (1999) Sedimentation of ${ }^{13} \mathrm{C}$-rich organic matter from Antarctic sea-ice algae: a potential indicator of past sea ice extent. Geology 27:331-334

Graeve M, Kattner G, Piepenburg D (1997) Lipids in Arctic benthos: Does the fatty acid and alcohol composition 
reflect feeding and trophic interactions? Polar Biol 18:53-61

Grebmeier JM, McRoy CP, Feder HM (1988) Pelagic-benthic coupling on the shelf of the northern Bering and Chukchi Seas. I. Food supply source and benthic biomass. Mar Ecol Prog Ser 48:57-67

Grebmeier JM, Smith WO, Conover RJ (1995) Biological processes on Arctic continental shelves: ice-ocean-biotic interactions. In: Smith WO, Grebmeier JM (eds) Arctic oceanography: marginal ice zones and continental shelves. American Geophysical Union, Washington, DC, p 231-261

Hansen AS, Nielsen TG, Levinsen H, Madsen SD, Thingstad TF, Hansen BW (2003) Impact of changing ice cover on pelagic productivity and food web structure in Disko Bay, West Greenland: a dynamic model approach. Deep-Sea Res I 50:171-187

Hegseth EN (1998) Primary production of the northern Barents Sea. Polar Res 17:113-123

Highsmith RC, Coyle KO (1990) High productivity of northern Bering Sea benthic amphipods. Nature 344:862-864

Hobson KA, Welch HE (1992) Determination of trophic relationships within a high arctic marine food web using $\delta^{13} \mathrm{C}$ and $\delta^{15} \mathrm{~N}$ analysis. Mar Ecol Prog Ser 84:9-18

Hobson KA, Ambrose WG, Renaud PE (1995) Sources of primary production, benthic-pelagic coupling, and trophic relationships within the Northeast Water Polynya: insights from $\delta^{13} \mathrm{C}$ and $\delta^{15} \mathrm{~N}$ analysis. Mar Ecol Prog Ser 128:1-10

Hobson KA, Fisk A, Karnovsky N, Holst M, Gagnon JM, Fortier M (2002) A stable isotope $\left(\delta^{13} \mathrm{C}, \delta^{15} \mathrm{~N}\right)$ model for the North Water food web: implications for evaluating trophodynamics and the flow of energy and contaminants. DeepSea Res II 49:5131-5150

Hoch MP, Snyder RA, Cifuentes LA, Coffin RB (1996) Stable isotope dynamics of nitrogen recycled during interactions among marine bacteria and protists. Mar Ecol Prog Ser 132:229-239

Hop H, Borgå K, Gabrielsen GW, Kleivane L, Skaare UJ (2002) Food web magnification of persistent organic pollutants in poikilotherms and homeotherms from the Barents Sea. Environ Sci Technol 36:2589-2597

Iken K, Bluhm BA, Gradinger R (2005) Food web structure in the high Arctic Canada Basin: evidence from $\delta^{13} \mathrm{C}$ and $\delta^{15} \mathrm{~N}$ analysis. Polar Biol 28:238-249

Jangoux M, Lawrence JM (1982) Echinoderm nutrition. Balkema, Rotterdam

Klekowski RZ, Weslawski JM (1991) Atlas of the marine fauna of southern Spitsbergen, Vol 2. Invertebrates, Part 1. Institute of Oceanology, Gdansk

Klekowski RZ, Weslawski JM (1992) Atlas of the marine fauna of southern Spitsbergen, Vol 2. Invertebrates, Part 2. Institute of Oceanology, Gdansk

Klekowski RZ, Weslawski JM (1997) Atlas of the marine fauna of southern Spitsbergen, Vol 2. Invertebrates, Part 3. Institute of Oceanology, Gdansk

Kling GW, Fry B, O'Brien WJ (1992) Stable isotopes and planktonic trophic structure in Arctic lakes. Ecology 73: 561-566

Kopczynska EE, Goeyens L, Semeneh M, Dehairrs F (1995) Phytoplankton composition and cell carbon distribution in Prydz Bay, Antarctica: relation to organic particulate matter and its $\delta^{13} \mathrm{C}$ values. J Plankton Res 17:685-707

Legendre L, Ackley SF, Dieckmann GS, Gulliksen B and 6 others (1992) Ecology of sea ice biota. 2. Global significance. Polar Biol 12:429-444

Lehmann MF, Bernasconi SM, Barbieri A, McKenzie JA (2002) Preservation of organic matter and alteration of its carbon and nitrogen isotope composition during simulated and in situ early sedimentary diagenesis. Geochim Cosmochim Acta 66:3573-3584

Loeng H (1991) Features of the physical oceanographic conditions of the Barents Sea. Polar Res 10:5-18

Lovvorn JR, Cooper LW, Brooks ML, De Ruyck CC, Bump JK, Grebmeier JM (2005) Organic matter pathways to zooplankton and benthos under pack ice in late winter and open water in late summer in the north-central Bering Sea. Mar Ecol Prog Ser 291:135-150

Machuline J (1998) The biology of calanoid copepods. Advances in biology 33. Academic Press, San Diego, CA

Macko SA, Estep MLF (1984) Microbial alteration of stable nitrogen and carbon isotopic compositions of organic matter. Org Geochem 6:787-790

McConnaughey T, McRoy CP (1979) Food-web structure and the fractionation of carbon isotopes in the Bering Sea. Mar Biol 53:257-262

McMahon K, Ambrose WG Jr, Johnson BJ, Sun MY, Lopez GR, Clough LM, Carrol ML (2006) Benthic community response to ice algae and phytoplankton in Ny Ålesund, Svalbard. Mar Ecol Prog Ser 310:1-14 (this volume)

Michel C, Nielsen TG, Nozais C, Gosselin M (2002) Significance of sedimentation and grazing by ice micro- and meiofauna for carbon cycling in annual sea ice (northern Baffin Bay). Aquat Microb Ecol 30:57-68

Michener RH, Schell DM (1994) Stable isotope ratios as tracers in marine and aquatic food webs. In: Lajtha K, Michener RH (eds) Stable isotopes in ecology and environmental science. Blackwell Scientific Publications, Oxford, p 138-157

Needoba JA, Waser NA, Harrison PJ, Calvert SE (2003) Nitrogen isotope fractionation in 12 species of marine phytoplankton during growth of nitrate. Mar Ecol Prog Ser 255:81-91

Niebauer HJ, Alexander VA, Henrichs SM (1990) Physical and biological oceanographic interactions in the spring bloom at the Bering Sea marginal ice zone. J Geophys Res 95:22229-22241

Olli K, Wexels Riser C, Wassmann P, Ratkova T, Arashkevich E, Pasternak A (2002) Seasonal variation in vertical flux of biogenic matter in the marginal ice zone and the central Barents Sea. J Mar Syst 38:189-204

Ostrom NE, Macko SA, Deibel D, Thompson RJ (1997) Seasonal variation in the stable carbon and nitrogen isotope biogeochemistry of a coastal cold ocean environment. Geochim Cosmochim Acta 61:2929-2942

Pennock JR, Velinsky DJ, Ludlam JM, Fogel MA (1996) Is topic fractionation of ammonium and nitrate during uptake by Skeletonema costatum: implications for $\delta^{15} \mathrm{~N}$ dynamics under bloom conditions. Limnol Oceanogr 41:451-459

Pethon P (1998) Aschehougs store fiskebok. Aschehoug, Stockholm (Aschehoug's fish guide, in Norwegian)

Piepenburg D, Ambrose WG, Brandt A, Renaud PE, Aherns MJ, Jensen P (1997) Benthic community patterns reflect water column processes in the Northeast Water polynya (Greenland). J Mar Syst 10:467-482

Poltermann M (2001) Arctic sea ice as feeding ground for amphipods - food sources and strategies. Polar Biol 24:89-96

Post DM (2002) Using stable isotopes to estimate trophic position: models, methods and assumptions. Ecology 83:703-718

Power M, Guiger KRRA, Barton DR (2003) Effects of temperature on isotopic enrichment in Daphnia magna: implications for aquatic food-web studies. Rapid Commun Mass Spectrom 17:1619-1625 
Rau GH, Takahashi T, Des Marais DJ, Repeta DJ, Martin JH (1992) The relationship between $\delta^{13} \mathrm{C}$ of organic matter and $\left[\mathrm{CO}_{2}(\mathrm{aq})\right]$ in ocean surface-water: data from a JGOFS site in the northeast Atlantic and a model. Geochim Cosmochim Acta 56:1413-1419

Ritzrau W, Thomsen L (1997) Spatial distribution of particle composition and microbial activity in benthic boundary layer (BBL) of the Northeast Water Polynya. J Mar Syst 10:415-428

Sakshaug E, Skjoldal HE (1989) Life at the ice edge. Ambio 18:60-67

Sato M, Sasaki H, Fukuchi M (2002) Stable isotopic compositions of overwintering copepods in the arctic and subarctic waters and implications to the feeding history. J Mar Syst 38:165-174

Saupe SM, Schell DM, Griffiths WB (1989) Carbon-isotope ratio gradients in western arctic zooplankton. Mar Biol 103:427-432

Scott CL, Falk-Petersen S, Sargent JR, Hop H, Lønne OJ, Poltermann M (1999) Lipids and trophic interactions of ice fauna and pelagic zooplankton in the marginal ice zone of the Barents Sea. Polar Biol 21:65-70

Scott CL, Falk-Petersen S, Gulliksen B, Lønne OJ, Sargent R (2001) Lipid indicators of the diet of the sympagic amphipod Gammarus wilkitzkii in the Maginal Ice Zone and in open waters of Svalbard (Arctic). Polar Biol 24:572-576

Sherr EB, Sherr BF, Wheeler PA, Thompson K (2003) Temporal and spatial variation in the stock of autotrophic and heterotrophic microbes in the upper water column of the central Arctic Ocean. Deep-Sea Res I 50:557-571

Editorial responsibility: Howard I. Browman (Associate Editor-in-Chief), Storebø, Norway
Strass VM, Nöthig EM (1996) Seasonal shifts in ice edge phytoplankton blooms in the Barents Sea related to the water column stability. Polar Biol 16:409-422

Syvertsen EE (1991) Ice algae in the Barents Sea: types of assemblages, origin, fate and role in the ice-edge phytoplankton bloom. Polar Res 10:277-288

Tamelander T, Heiskanen AS (2004) Effects of spring bloom phytoplankton dynamics and hydrography on the composition of settling material in the coastal northern Baltic Sea. J Mar Syst 52:217-234

Thomsen L, Graf G (1994) Boundary layer characteristics of the continental margin of the western Barents Sea. Oceanol Acta 17:597-607

Verity GV, Wassmann P, Freischer ME, Howard-Jones MH, Allen AE (2002) Grazing of phytoplankton by microzooplankton in the Barents Sea during early summer. J Mar Syst 38:109-123

von Dorrien CF (1993) Ecology and respiration of selected Arctic benthic fish species. Ber Polarforsch 125:1-99

Wada E, Terazaki M, Kabaya Y, Nemoto T (1987) ${ }^{15} \mathrm{~N}$ and ${ }^{13} \mathrm{C}$ abundance in the Antarctic Ocean with emphasis on the biogeochemical structure of the food web. Deep-Sea Res 34:829-841

Wassmann P, Andreassen I, Reigstad R, Slagstad D (1996) Pelagic-benthic coupling in the Nordic Seas: the role of episodic events. PSZN I: Mar Ecol 17:447-471

Werner I, Auel H, Kiko R (2004) Occurrence of Anonyx sarsi (Amphipoda: Lysianassoidea) below Arctic pack ice: An example for cryo-benthic coupling? Polar Biol 27: $474-481$

Submitted: May 9, 2005; Accepted: September 9, 2005

Proofs received from author(s): February 21, 2006 